\title{
Expressional Patterns of Connexin Isoforms in the Rat Epididymal Fat during Postnatal Development
}

\author{
${ }^{\dagger}$ Ki-Ho Lee and Nan Hee Kim \\ Dept. of Biochemistry and Molecular Biology, College of Medicine, Eulji University, Daejeon 34824, Korea
}

\begin{abstract}
In the multicellular tissue, cell-cell interaction is important for a precise control of its function. The exchange of signaling molecules between adjacent cells via connexon allows the functional harmony of cells in the tissue. The present research was to determine the presence and expressional patterns of connexin $(C x)$ isoforms in the rat epididymal fat during postnatal development using quantitative real-time polymerase chain reaction (PCR) analysis. Of $13 C x$ isoforms examined, expression of $11 C x$ isoforms in the epididymal fat during postnatal development was detected. These $C x$ isoforms include $C x 26, C x 31, C x 31.1, C x 32, C x 33, C x 36, C x 37, C x 40, C x 43, C x 45$, and $C x 50$. Expressional levels of all $C x$ isoforms at 1 and 2 years of age were significantly higher than those at the early postnatal ages, such as 7 days, 14 days, and 24 days of ages. Except $C x 33$ and $C x 43$, the transcript levels of rest $C x$ isoforms at 1 year of age were significantly lower than that at 2 years of age. In addition, expressional patterns of $C x$ isoforms between 7 days and 5 months of ages generally varied according to the isoform. The existence of various $C x$ isoforms in the rat epididymal fat has been identified and expression of each $C x$ isoform in the epididymal fat during postnatal development has shown a particular pattern, distinguishable from the others. To our knowledges, this is the first report showing expressional patterns of $C x$ isoforms at transcript level in the epididymal fat at various postnatal ages.
\end{abstract}

Key words : Connexin, Quantitative real-time polymerase chain reaction (PCR), Epididymal fat, Postnatal development, Gene expression

\section{INTRODUCTION}

Adipose tissue is composed of various cell types, including adipocyte (fat cell), macrophages, endothelial cells, fibroblasts, and adipose precursor cells (Frühbeck, 2008). Adipose tissue is commonly found in all mammalian species as well as a number of non-mammalian species (Hausman et al., 2001). Formation of adipose tissue in mammals begins in utero and continues throughout life time. Based on histological and molecular characteristics, mammalian adipose tissue is separated into two types, white adipose tissue (WAT) and brown adipose tissue (BAT) (Berry et al., 2013). It is generally considered that WAT is specialized for energy storage and BAT is chiefly involved in energy consumption and heat generation (Berry et al., 2013). In spite of the presence of functional and morphological differences, adipocytes in WAT and BAT are originated from a common stellate or fusiform precursor cells derived from mesenchymal cells (Frühbeck, 2008).

Adipose tissue usually exists in a depot form, and there are two classes of WAT, subcutaneous and visceral WAT, according to regional, developmental timing, and molecu-

Manuscript received January 30, 2018, Received in revised form March 10, 2018, Accepted March 17, 2018

${ }^{\dagger}$ Corresponding Author : Ki-Ho Lee, Department of Biochemistry and Molecular Biology, Eulji University, Daejeon 34824, Korea. Tel: +82-42-259-1643, Fax: +82-42-259-1649, E-mail: kiholee@eulji.ac.kr

This is an Open Access article distributed under the terms of the Creative Commons Attribution Non-Commercial License (http:// creative-commons.org/licenses/by-nc/3.0) which permits unrestricted non-commercial use, distribution, and reproduction in any medium, provided the original work is properly cited. 
lar features, and biological functions (Berry et al., 2013). Visceral WAT is further divided into retroperitoneal, perigonadal, and mesenteric WATs, which have specific and distinct morphology and texture (Berry et al., 2013). The epididymal fat depot is included in perigonadal WAT and embeds the efferent ductules located between the testis and the epididymis. In the rat, the weight of epididymal fat during postnatal development becomes remarkably increased in several hundred-fold (Hubbard \& Matthew, 1971; Cleary et al., 1977). The increase of epididymal fat weight with aging is due to not only an increase of fat cell number but also an increase of fat cell size (Cleary et al., 1977). In addition to the changes in fat cell, weight of non-lipid filled cells in the epididymal fat during postnatal development is also increased at a lower rate than that of fat cell (Cleary et al., 1977). Even though the gross change of epididymal fat from the early pubertal age to the adult age has been briefly studied, the change of epididymal fat at the prepubertal and/or the elderly age has not been examined yet.

Cell-cell communication within multicellular tissue is an important biological phenomenon to permit a functional accordance of tissue. Cellular communication is usually accomplished by three junctional complexes, including tight junction, adherens junction, and gap junction (Cyr, 2011). Of these junctional complexes present within multicellular tissue, gap junction plays various important roles by mediating direct communication between adjacent cells (Cyr, 2011). Gap junction is consisted of homomeric or heteromeric hemichannel, called connexon, and each connexon is made of six connexin $(C x)$ molecules (Cyr, 2011). Direct exchanges of small molecules, such as signaling particles, metabolites, and even ribonucleic acid (RNAs), between neighboring cells are permitted through connexon (Goodenough et al., 1996). There are $20 C x$ isoforms identified in mammals to date, and expression of $C x$ isoforms in various tissues has been examined from a number of researches (Goodenough et al., 1996; Willecke et al., 2002). Some $C x$ isoforms are present in a broad range of tissues and/or cell types, while expression of certain $C x$ isoforms is restricted into specific cell types (Pointis et al., 2005). Even though it is not largely examined, expression of $C x$ isoforms and possible role of $C x$ isoforms in fat tissues have been studied (Burke et al., 2014; Kim et al., 2017). Among the male reproductive tract, expression of $C x$ isoforms in the testis and epididymis has been extensively evaluated by other and our previous researches (Hejmej et al., 2007; Han \& Lee, 2013). However, it is hard to find any report on the presence and/or expression of $C x$ isoforms in the epididymal fat.

Thus, the present research was focused to examine the presence of $C x$ isoforms in the rat epididymal fat at messenger RNA (mRNA) level and, if so, expressional patterns of $C x$ isoforms during postnatal development from the neonatal age to extremely old age.

\section{MATERIALS AND METHODS}

\section{Experimental animals and collection of the tissue}

Male pups of Sprague Dawley rat were obtained from pregnant female rats $(n=10)$ caged individually upon the delivery (Samtako, OSan, Korea). The neonatal and young male rats at 1 week $(n=10), 14$ days $(n=10)$, and 24 days $(n=8)$ were used for the present research. Male rats at 44 days of age $(n=7)$ were purchased from Samtako. These animals were allowed free access to food and water throughout the experiment. Male Sprague Dawley rats at 5 months $(n=5), 1$ year $(n=3)$, and 2 years $(n=3)$ of ages were kindly supported by Aging Tissue Bank (Department of Pharmacology, Pusan National University, S. Korea).

To collect the epididymal fat, the experimental animal was anesthetized by $\mathrm{CO}_{2}$ stunning, and an opening was made on lower abdominal area by a pair of scissors. The entire reproductive tract, including epididymal fat, testis, and epididymis, was dissected out and rapidly placed in cold-PBS (phosphate-buffered saline) containing dish. The epididymal fat was separated from the rest of reproductive 
tract, and the efferent ductules embedded within the epididymal fat were carefully removed. The fat was quickly washed with a fresh cold-PBS and frozen in liquid nitrogen. The fat tissue stored in $-80^{\circ} \mathrm{C}$ was used for total RNA isolation within a week after the tissue isolation.

\section{Isolation of total RNA from the epididymal fat} and construction of the first-stranded complementary DNA (cDNA)

About $20 \mathrm{mg}$ of the epididymal fat tissue was homogenized in easy-Blue total RNA extract solution (iNtRON Biotech, Sungnam, S. Korea) by using a polytron homogenizer (Fisher Scientific, Pittsburgh, USA). Total RNA pellet was collected by the sequential addition of chloroform and isopropanol, and an air-dried pellet was responded in DEPC- $\mathrm{dH}_{2} \mathrm{O}$. The qualitative and quantitative evaluations of isolated total RNA were carried out by $2 \%$ agarose gel electrophoresis and a NanoDrop Lite spectrophotometry (Thermo Scientific, Wilmington, DE), respectively. The total RNA was stored in $-80^{\circ} \mathrm{C}$ until used for reverse transcription (RT) reaction.

The ImProm-II ${ }^{\mathrm{TM}}$ reverse transcription system (Promega, Madison, USA) was used to perform the RT reaction with $1 \mu \mathrm{g}$ of total RNA. A RT mixture having total RNA, oligodT primer, dNTPs, RTase, and buffer in a total volume of $20 \mu \mathrm{L}$ was exposed to $25^{\circ} \mathrm{C}$ for $5 \mathrm{~min}$, followed by an incubation at $42^{\circ} \mathrm{C}$ for $90 \mathrm{~min}$ and $70^{\circ} \mathrm{C}$ for $15 \mathrm{~min}$. Generated cDNA was immediately used for quantitative real-time polymerase chain reaction (PCR) analysis.

\section{Quantitative real-time polymerase chain reaction} analysis and data analysis

Table 1 shows the oligonucleotide primers examined in the present research for real-time PCR analysis. The primer design was performed with Primer 3 software (http://www.bio neer.co.kr/cgi-bin/primer/primer3.cgi: Whitehead Institute/ MIT Center for Genomes Research, USA). Initially, oligonucleotide primers of $13 C x$ isoforms were designed and tested for the expression in the epididymal fat. However, expression of $C x 30$ and $C x 30.1$ in the epididymal fat was not detected in the epididymal fat throughout the postnatal development. Thus, the sequence information of $C \times 30$ and Cx30.1 was excluded from Table 1.

To perform quantitative real-time PCR, $1 \mu \mathrm{L}$ of cDNA was mixed with 10 pmol of each primer, $7 \mu \mathrm{L}$ of $\mathrm{iQ}^{\mathrm{TM}} \mathrm{SYBR}^{\circledR}$ Green Supermix (Bio-Rad Laboratories, Hercules, CA), and DNase (deoxyribonuclease)-free $\mathrm{dH}_{2} \mathrm{O}$ to make a final volume of $20 \mu \mathrm{L}$. The mixture was allowed for a pre-denaturation step at $95^{\circ} \mathrm{C}$ for $5 \mathrm{~min}$. Then, the PCR procedure was carried out in a thermocycler (Bio-Rad Laboratories) with cycles of denaturation at $95^{\circ} \mathrm{C}$ for $30 \mathrm{sec}$, annealing at $\mathrm{T}_{\mathrm{m}}$ for $30 \mathrm{sec}$, and extension at $72^{\circ} \mathrm{C}$ for $30 \mathrm{sec}$. At the last, an extension step at $72^{\circ} \mathrm{C}$ for $10 \mathrm{~min}$ was added to each PCR. The size of expected PCR product was checked by $1.2 \%$ agarose gel electrophoresis. Beta-actin $(A c t b)$ was included as an internal PCR control.

Independent quadruplication of RT reaction and PCR for each postnatal age was executed to obtain a mean and a standard error. The PCR result was presented in the relative ratio of expressional level between $A c t b$ and $C x$ isoform. Statistical comparison among the transcript level of different postnatal ages for each $C x$ isoform was achieved by one-way ANOVA, followed by Duncan's test, a posthoc analysis. If $p<0.05$, means between age groups were judged as statistically significant.

\section{RESULTS}

\section{Expressional patterns of $C \times 26$ and $C \times 31$ expres-} sion in the epididymal fat of rat during postnatal period

Expressional level of $C x 26$ in the epididymal fat of rat at 7 days of postnatal age was not significantly changed until 45 days of age, while an expressional surge of $C x 26$ was detected at 5 months of age (Fig. 1A). The expressional level of $C x 26$ at 1 year of age was about 4 times higher than that at 5 months of age (Fig. 1A). Compared with the 
Table 1. Information for oligonucleotide primers utilized for quantitative real-time PCR analysis

\begin{tabular}{|c|c|c|c|}
\hline Gene & $\begin{array}{l}\text { Primer sequence } \\
\qquad\left(5^{\prime} \rightarrow 3^{\prime}\right)\end{array}$ & $\begin{array}{c}\mathrm{T}_{\mathrm{m}} \\
\left({ }^{\circ} \mathrm{C}\right)\end{array}$ & $\begin{array}{l}\text { PCR product size } \\
\text { (bps) }\end{array}$ \\
\hline$G j b 2(C x 26)$ & (F) TCCTCTTCATCTTCCGCATC & 55 & 233 \\
\hline (NM_001004099) & (R) CCGTTTCTTTTCGTGTCTCC & & \\
\hline$G j b 3(C x 31)$ & (F) TTGAGCGGTGTGAACCAGTA & 58 & 193 \\
\hline (NM_019240) & (R) TGTTGGAGATGGGGAAGAAG & & \\
\hline Gjb5 (Cx31.1) & (F) CATCGTCTGCATCCTGCTTA & 55 & 165 \\
\hline (NM_019241) & (R) ATGAGGTCGCTTGAGAGGAA & & \\
\hline Gjb1 (Cx32) & (F) AGAATCATGGTGCTGGTGGT & 58 & 235 \\
\hline (NM_017251) & (R) CCTCAAGCCGTAGCATTTTC & & \\
\hline Gja6 (Cx33) & (F) TGAGAGGCAGATTGCTGCTA & 58 & 221 \\
\hline (NM_019308) & (R) AGACACCATTGACACCACCA & & \\
\hline Gjd2 (Cx36) & (F) TCTGGAGATTGGGTTTCTGG & 58 & 231 \\
\hline (NM_019281) & (R) CGGACAGCCAGTTTGATCTT & & \\
\hline Gja4 (Cx37) & (F) AGTGTCTGTACCTTGGATGCC & 55 & 223 \\
\hline (NM_021654) & (R) CAGCACACTTAGCCAAGAGC & & \\
\hline $\operatorname{Gja} 5(C x 40)$ & (F) ATACCATTCAGCCTGGTTGC & 58 & 189 \\
\hline (NM_019280) & (R) CGGCCTCTTTAGCTTTCTCA & & \\
\hline Gjal (Cx43) & (F) AGCAAGCTAGCGAGCAAAAC & 55 & 151 \\
\hline (NM_012567) & (R) GAGTTCATGTCCAGCAGCAA & & \\
\hline $\operatorname{Gja} 7(C x 45)$ & (F) GATCATCCTGGTTGCTACTC & 58 & 173 \\
\hline (NM_001085381) & (R) GATCCTCTTCATGGTCCTCT & & \\
\hline Gja8 $(C x 50)$ & (F) CCACTCCATTGCAGTTTCCT & 58 & 211 \\
\hline (NM_153465.2) & (R) AGAAGGCAGGGTTTCTTGGT & & \\
\hline$A c t b$ & (F) ACCTTCAACACCCCAGCCATGTACG & 55 & 698 \\
\hline (NM_031144.3) & (R) CTGATCCACATCTGCTGGAAGGTGG & & \\
\hline
\end{tabular}

PCR, polymerase chain reaction, $C x$, connexin; Gja, gap junction protein, alpha; Gjb, gap junction protein, beta; Gjd, gap junction protein, delta; Actb, actin, beta.

level of Cx26 mRNA at 1 year of age, over 7.5 -fold increase of $C x 26$ transcript level was observed at 2 years of postnatal age (Fig. 1A).

Expression of $C x 31$ was first significantly increased at 14 days of age, and the level of $C \times 31$ transcript was remained in steady until 24 days of age (Fig. 1B). However, the level of Cx31 mRNA was significantly decreased and became the lowest level during postnatal development (Fig. 1B). Expressional level of $C x 31$ at 5 months of age was higher than 14 and 24 days of ages, and a huge increase of $C \times 31$ 
(A)

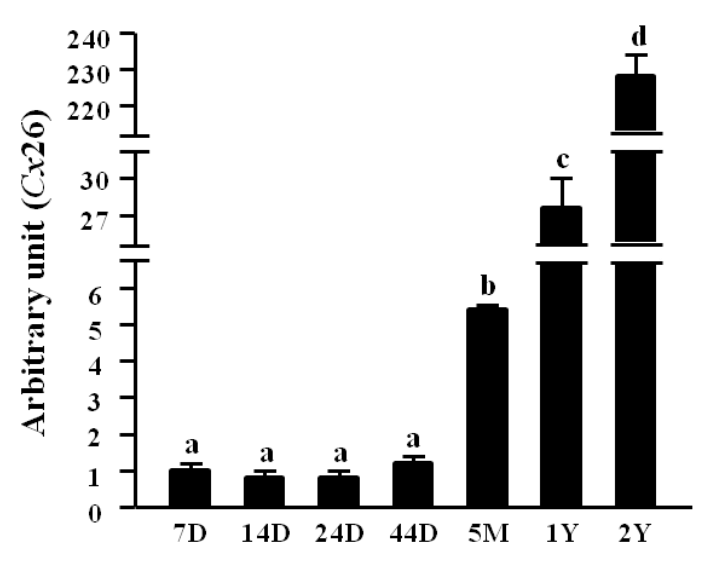

Experimental group
(B)

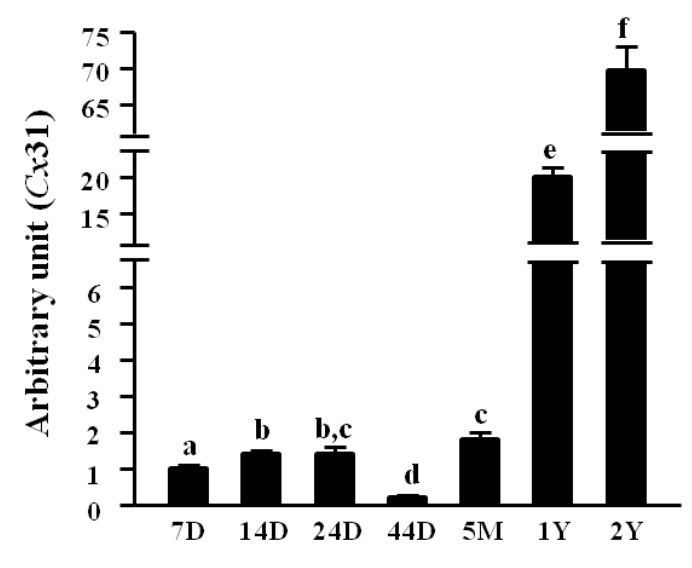

Experimental group

Fig. 1. Expressional patterns of $C x 26$ and $C x 31$ in the rat epididymal fat during postnatal period. The relative expressional levels of $C x 26$ (A) and $C x 31$ (B) are shown here. Different letters indicate statistical significances at $p<0.05$. $C x$, connexin; $\mathrm{D}$, day; $\mathrm{M}$, month; $\mathrm{Y}$, year.

expression was detected at 1 year of age (Fig. 1B). The level of $C \times 31$ transcript at 2 years of age was more than 3 times higher than that at 1 year of age (Fig. 1B).

\section{Expressional patterns of $C \times 31.1$ and $C \times 32$ expres-} sion in the epididymal fat of rat during postnatal period

There was no significant change of $C x 31.1$ transcript level until 5 months of age (Fig. 2A). However, a tremendous increase, about 30 times, of $C \times 31.1$ mRNA level was detected at 1 year of age, followed by an additional increase of the transcript level at 2 years of age (Fig. 2A).

A significant increase of $C x 32$ transcript level was observed at 14 days of age, followed by a drop at 24 days of age to the level of $C x 32$ mRNA at 7 days of postnatal age (Fig. 2B). No significant change of Cx32 transcript level was detected until 44 days of age (Fig. 2B). However, the level of Cx32 mRNA was significantly increased at 5 months of age (Fig. 2B). Expression of Cx32 in the epididymal fat was significantly increased at 1 year of age, compared with that at 5 months of age (Fig. 2B). A vast increase, over 25-fold, of $C \times 32$ transcript level at 2 years of age was followed (Fig. 2B).

\section{Expressional patterns of $C \times 33$ and $C \times 36$ expres-} sion in the epididymal fat of rat during postnatal period

Expressional level of $C x 33$ in the rat epididymal fat was first significantly increased at 14 days of age, and an additional increase of $C \times 33$ transcript level was observed at 44 days of postnatal age (Fig. 3A). A further induction of $C x 33$ expression was found at 5 months of age, followed by mostly 5-fold increase of $C \times 33$ transcript level at 1 year of age (Fig. 3A). But, the level of $C x 33$ transcript at 2 years of postnatal age was significantly decreased (Fig. 3A).

There was no significant change of $C x 36$ transcript level until 24 days of age (Fig. 3B). However, an increase of Cx36 mRNA level was observed at 44 days of age, and the level of $C x 36$ transcript at 5 months of age was significantly higher than that at 44 days of age (Fig. 3B). A great jump of $C \times 36$ transcript level was detected at 1 year of age, followed by a further significant increase of the level at 2 years of age (Fig. 3B).

\section{Expressional patterns of $C \times 37$ and $C \times 40$ expres-} sion in the epididymal fat of rat during postnatal period

Fig. 4A shows the expressional pattern of $C x 37$ in the rat 
(A)

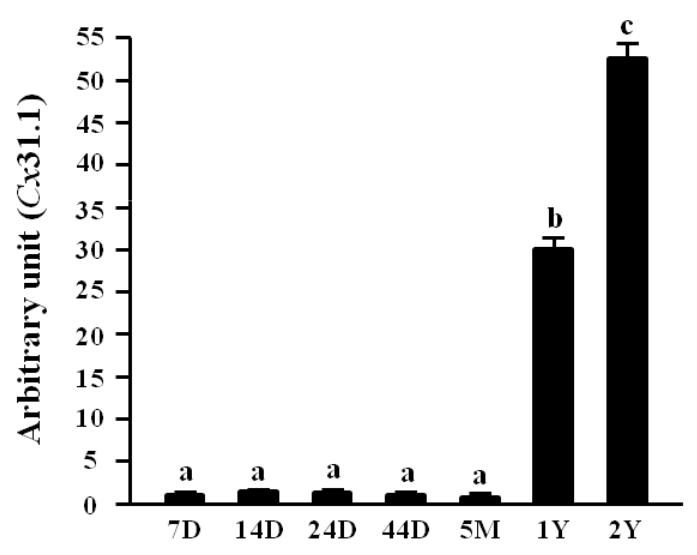

Experimental group
(B)

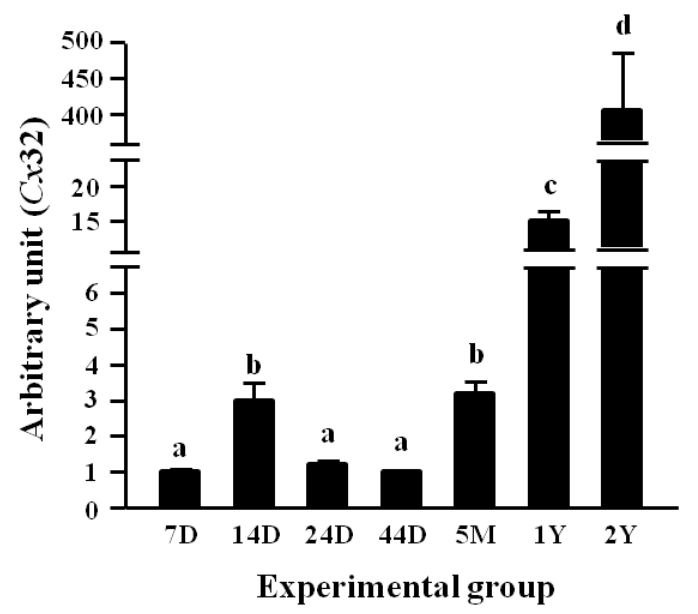

Fig. 2. Expressional patterns of $\boldsymbol{C x} 31.1$ and $C x 32$ in the rat epididymal fat during postnatal period. The relative expressional levels of $C x 31.1$ (A) and $C x 32$ (B) are shown here. Different letters indicate statistical significances at $p<0.05$. $C x$, connexin; D, day; $\mathrm{M}$, month; $\mathrm{Y}$, year.

(A)

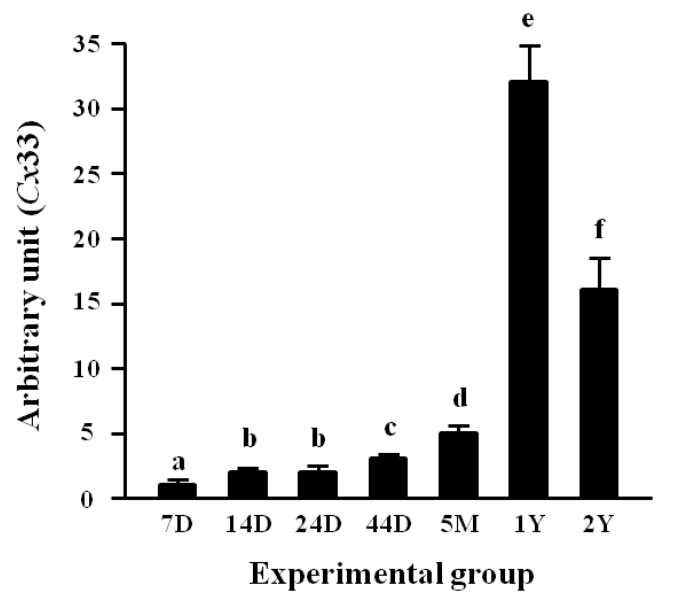

(B)

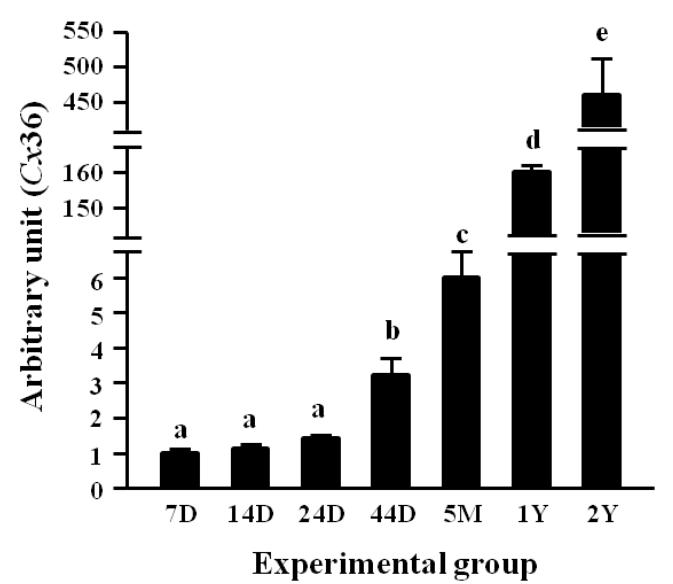

Fig. 3. Expressional patterns of $C x 33$ and $C x 36$ in the rat epididymal fat during postnatal period. The relative expressional levels of $C x 33$ (A) and $C x 36$ (B) are shown here. Different letters indicate statistical significances at $p<0.05$. $C x$, connexin; D, day; $\mathrm{M}$, month; $\mathrm{Y}$, year.

epididymal fat during postnatal development. The levels of Cx37 transcript at 14 and 24 days of age were significantly higher than that at 7 days of age (Fig. 4A). But, transcript level of $C \times 37$ at 44 days and 5 months of age was lower than those at 14 and 24 days of age but still higher than that at 7 days of age (Fig. 4A). An increase of $C x 37$ mRNA level was found at 1 year of age, and a rise of $C \times 37$ tran- script level was additionally detected at 2 years of age (Fig. 4A).

The level of $C x 40$ transcript in the rat epididymal fat was significantly induced at 14 days of age, compared with that at 7 days of age (Fig. 4B). Another significant increase of Cx40 mRNA level was detected at 24 days of age, followed by a quick drop of the level at 44 days of age (Fig. 
(A)

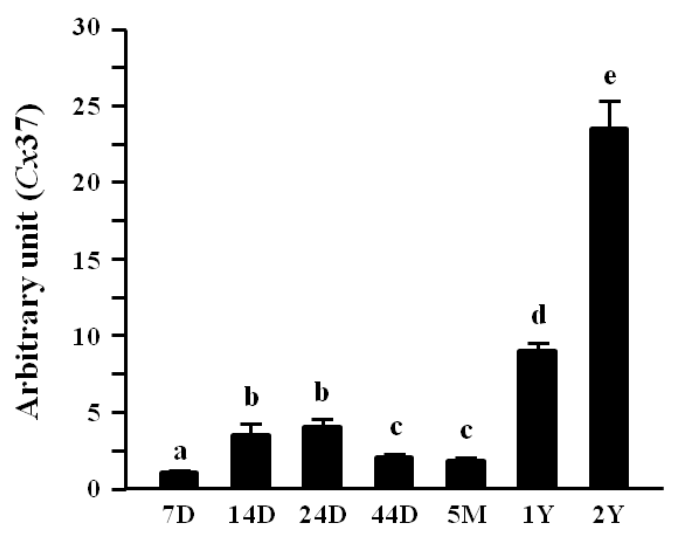

Experimental group
(B)

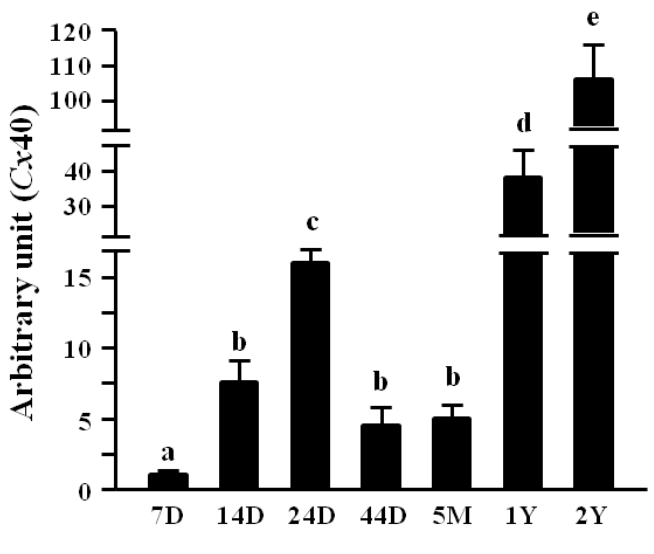

Experimental group

Fig. 4. Expressional patterns of $\boldsymbol{C x 3 7}$ and $\boldsymbol{C x} 40$ in the rat epididymal fat during postnatal period. The relative expressional levels of $C x 37$ (A) and $C x 40$ (B) are shown here. Different letters indicate statistical significances at $p<0.05$. $C x$, connexin; D, day; M, month; Y, year.

4B). Compared with the level of Cx40 transcript at 5 months of age, over 7-fold increase of Cx40 transcript level was found at 1 year of age (Fig. 4B). Expressional level of $C x 40$ in the rat epididymal fat at 2 years of age was 2 times higher than that at 1 year of age (Fig. 4B).

5. Expressional patterns of $C x 43, C x 45$, and $C \times 50$ expression in the epididymal fat of rat during postnatal period

Expressional level of $C x 43$ in the rat epididymal fat was not significantly changed until 24 days of age (Fig. 5A). There was the first significant increase of $C \times 43$ transcript level at 44 days of age, followed by a drop of the level at 5 months of age (Fig. 5A). However, another significant surge of $C x 43 \mathrm{mRNA}$ abundance was detected at 1 year of postnatal age (Fig. 5A).

The transcript level of $C x 45$ was significantly increased at 24 days of age, and a further increase of $C \times 45$ mRNA level was followed at 44 days of age (Fig. 5B). The level of $C \times 45$ transcript was significantly decreased at 5
(A)

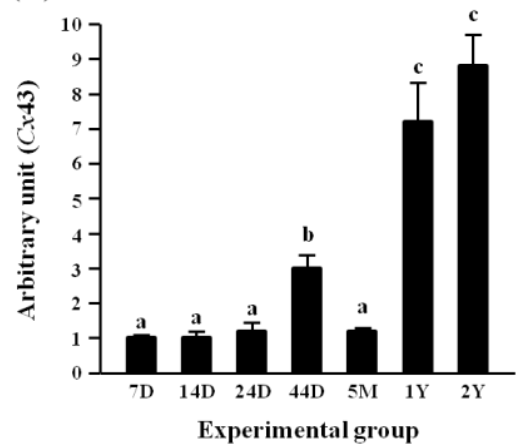

(B)

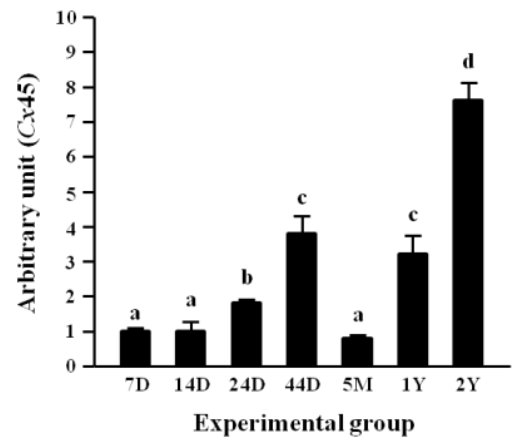

(C)

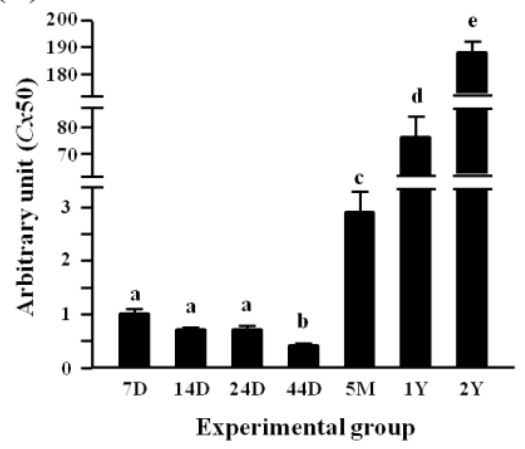

Fig. 5. Expressional patterns of $C x 43, C x 45$ and $C x 50$ in the rat epididymal fat during postnatal period. The relative expressional levels of $C x 43$ (A), $C x 45$ (B), and $C x 50$ (C) are shown here. Different letters indicate statistical significances at $p<0.05$. $C x$, connexin; D, day; M, month; Y, year. 
months of age, but was again increased at 1 year of age (Fig. 5B). The highest expression level of $C x 45$ was observed at 2 years of age (Fig. 5B).

The transcript level of Cx50 was not changed until 24 days of age, followed by a significant decrease at 44 days of postnatal age (Fig. 5C). However, a surge of Cx50 transcript level was found at 5 months of age (Fig. 5C). The level of Cx50 transcript at 1 year of age was about 25 times higher than that at 5 months of age (Fig. 5C). The transcript level of $C x 50$ at 2 years of postnatal age was over 1-fold higher than that at 1 year of age (Fig. 5C).

\section{DISCUSSION}

The present research shows the presence of several $C x$ isoforms in the epididymal fat and different expressional patterns of $C x$ isoforms during postnatal development. In general, compared with the transcript level of $C x$ isoforms at the neonatal age, the levels of all $C x$ isoforms at the old age, 1 year and 2 years of ages, are greatly increased in several folds, even hundreds folds. Even though expression of some $C x$ isoforms is steadily increased from the neonatal age to the adult age, expressional patterns of other $C x$ isoforms are fluctuated.

Unlike other tissues in the male reproductive tract, relatively little attention is paid to the function and necessity of the epididymal fat. There are some research reports showing a biological function of the epididymal fat on spermatogenesis. Surgical removal of the epididymal fat results in a decrease of seminiferous tubules in size and the cease of normal spermatogenesis in the testis (Chu et al., 2010). However, the removal of the epididymal fat dose not influence on testosterone production in the testis, indicating the existence of the epididymal fat-derived factor(s) involving in regulation of spermatogenesis in the testis (Chu et al., 2010). The epididymal fat expresses a number of adipose genes at a relatively high level, including leptin, adiponectin, and perilipin (Liu et al., 2011). In addition, it has been observed that the aging could give an impact on global gene expression in the epididymal fat (Liu et al., 2011). Pinterova et al (2000) have found that the rat epididymal fat expresses all components of renin-angiotensin system, including renin, angiotensinogen, and angiotensinconverting enzyme, which is presumably involved in metabolic pathway or in the regulation of blood flow. These findings suggest that the epididymal fat would have a variety of physiological functions presumably involved in male reproduction.

The epididymal fat becomes greatly increased in weight with aging as a consequence of increases of fat cell size and number (Cleary et al., 1977). Not only the age but also other factors, such as sex and food intake, could influence on weight gain of the epididymal fat during postnatal development (Hubbard \& Matthew, 1971). In addition, functional impairment of certain genes could induce abnormal hypertrophy of the epididymal fat. For example, leptindeficient $(o b / o b)$ or leptin receptor-deficient $(d b / d b)$ mouse has extremely heavy epididymal fat with increases of fat cell size and number (Johnson \& Hirsch, 1972). Interestingly, the epididymal fat of estrogen receptor $\alpha(\mathrm{ER} \alpha)$ knockout $(\alpha \mathrm{ERKO})$ male mouse is heavier than that of wild-type mouse throughout entire postnatal period, and difference of the epididymal fat weight between $\alpha E R K O$ mouse and wild-type mouse becomes more clear as ages (Heine et al., 2000). Moreover, the exposure to exogenous compounds also gives an impact on weight of the epididymal fat. The oral administration of genistein, an estrogenic phytoestrogen, results in increases of epididymal fat weight and fat cell size (Penza et al., 2006). The presence and expression of ER $\alpha$ and androgen receptor in the epididymal fat have been reported (Dieudonne et al., 1995; Metz et al., 2016). Together, these observations suggest that the development of epididymal fat during postnatal period could be influenced by various intrinsic factor(s) as well as exogenous compounds. 
A limited number of researches have demonstrated the presence and possible biological function of $C x$ isoforms in the epididymal fat (Zhu et al., 2016; Kim et al., 2017). Yanagiya et al (2007) have demonstrated that functional inhibition of gap junctional complex by $18 \alpha$-glycyrrhetinic acid results in expressional reduction of several molecules involving in mitotic clonal expansion during adipogenesis. In addition, down-regulation of $C x 43$ by small interfering RNA in 3T3-L1 cells causes a decrease of CCAAT/ enhancer-binding protein $\beta(\mathrm{C} / \mathrm{EBP} \beta)$ expression (Yanagiya et al., 2007). The $C x$ isoforms function not only as a type of cell junctions but also as a hemichannel allowing direct exchange of small molecules between neighboring cells (Goodenough et al., 1996). Thus, it is speculated that expressional changes of $C x$ isoforms in the rat epididymal fat during postnatal development would relate with modification of adipogenic capacity and function of epididymal fat cells with aging. Expressional alteration of $C x$ isoforms is closely associated with the development of diseases, including atherosclerotic plaques (Kwak et al., 2002). This information suggests that increases of $C x$ isoform expression in epidydimal fat at the old age would associate with onset and/or development of diverse age-related diseases and symptoms.

To our knowledge, the present research is the first report showing the presence and expressional patterns of multi$C x$ isoforms in the rat epididymal fat during postnatal development. Based on current and other's findings, expression of $C x$ isoforms in the rat epididymal fat seems to be closely associated with the change of epididymal fat weight during postnatal development. However, there are some questions on expression of $C x$ isoforms in the epididymal fat to be answered. For examples, which cell type(s) in the epididymal fat tissue does express $C x$ isoforms? Which factor(s) causes differential expression of $C x$ isoforms during postnatal period and what are regulatory mechanisms on expression of $C x$ isoforms in the epididymal fat tissue? What is the biological function(s) of $C x$ isoforms in the epididymal fat?

\section{ACKNOWLEDGEMENTS}

This research was supported by Basic Science Research Program through the National Research Foundation of Korea (NRF) funded by the Ministry of Education (2017R1D1A 1B03030209).

\section{REFERENCES}

Berry DC, Stenesen D, Zeve D, Graff JM (2013) The developmental origins of adipose tissue. Development 140:3939-3949.

Burke S, Nagajyothi F, Thi MM, Hanani M, Scherer PE, Tanowitz HB, Spray DC (2014) Adipocytes in both brown and white adipose tissue of adult mice are functionally connected via gap junctions: Implications for chagas disease. Microbes Infect 16:893-901.

Chu Y, Huddleston GG, Clancy AN, Harris RBS, Bartness TJ (2010) Epididymal fat is necessary for spermatogenesis, but not testosterone production or copulatory behavior. Endocrinology 151:5669-5679.

Cleary MP, Greenwood MRC, Brasel JA (1977) A multifactor analysis of growth in the rat epididymal fat pad. J Nutr 107:1969-1974.

Cyr DG (2011) Connexins and pannexins: Coordinating cellular communication in the testis and epididymis. Spermatogenesis 1:325-338.

Dieudonne MN, Pecquery R, Leneveu MC, Jaubert AM, Giudicelli Y (1995) Androgen receptors in cultured rat adipose precursor cells during proliferation and differentiation: Regional specificities and regulation by testosterone. Endocrine 3:537-41.

Frühbeck G (2008) Overview of adipose tissue and its role in obesity and metabolic disorders. Methods Mol Biol 456:1-22. doi: http://doi.org/10.1007/978-1-59745-245-8_1

Goodenough DA, Goliger JA, Paul DL (1996) Connexins, 
connexons, and intercellular communication. Annu Rev Biochem 65:475-502.

Han SY, Lee KH (2013) The expression patterns of connexin isoforms in the rat caput epididymis during postnatal development. J Anim Sci Technol 55:249-255.

Hausman DB, DiGirolamo M, Bartness TJ, Hausman GJ, Martin RJ (2001) The biology of white adipocyte proliferation. Obes Rev 2:239-254.

Heine PA, Taylor JA, Iwamoto GA, Lubahn DB, Cooke PS (2000) Increased adipose tissue in male and female estrogen receptor- $\alpha$ knockout mice. Proc Natl Acad Sci USA 97:12729-12734.

Hejmej A, Kotula-Balak M, Sadowska J, Bilińska B (2007) Expression of connexin 43 protein in testes, epididymides and prostates of stallions. Equine Vet J 39:122-127.

Hubbard RW, Matthew WT (1971) Growth and lipolysis of rat adipose tissue: Effect of age, body weight, and food intake. J Lipid Res 12:286-293.

Johnson PR, Hirsch J (1972) Cellularity of adipose depots in six strains of genetically obese mice. J Lipid Res 13:2-11.

Kim SN, Kwon HJ, Im SW, Son YH, Akindehin S, Jung YS, Lee SJ, Rhyu IJ, Kim IY, Seong JK, Lee J, Yoo HC, Granneman JG, Lee YH (2017) Connexin 43 is required for the maintenance of mitochondrial integrity in brown adipose tissue. Sci Rep 7:7159. doi: https://doi. org/10.1038/s41598-017-07658-y

Kwak BR, Mulhaupt F, Veillard N, Gros DB, Mach F (2002) Altered pattern of vascular connexin expression in atherosclerotic plaques. Arterioscler Thromb Vasc Biol 22:225-230.

Liu LF, Shen WJ, Ueno M, Patel S, Kraemer FB (2011) Characterization of age-related gene expression profiling in bone marrow and epididymal adipocytes. BMC
Genomics 12:212. doi: https://doi.org/10.1186/14712164-12-212.

Metz L, Gerbaix M, Masgrau A, Guillet C, Walrand S, Boisseau N, Boirie Y, Yves, Courteix D (2016) Nutritional and exercise interventions variably affect estrogen receptor expression in the adipose tissue of male rats. Nutr Res 36:280-289.

Penza M, Montani C, Romani A, Vignolini P, Pampaloni B, Tanini A, Brandi ML, Alonso-Magdalena P, Nadal A, Ottobrini L, Parolini O, Bignotti E, Calza S, Maggi A, Grigolato PG, Lorenzo DD (2006) Genistein affects adipose tissue deposition in a dose-dependent and gender-specific manner. Endocrinology 147:5740-5751.

Pinterova L, Krizanova O, Zorad S (2000) Rat epididymal fat tissue express all components of the renin-angiotensin system. Gen Physiol Biophys 19:329-334.

Pointis G, Fiorinin C, Defamie N, Segretain D (2005) Gap junctional communication in the male reproductive system. Biochim Biophy Acta 1719:102-116.

Willecke K, Eiberger J, Degen J, Eckardt D, Romualdi A, Güldenagel M, Deutsch U, Sohl G (2002) Structural and functional diversity of connexin genes in the mouse and human genome. Biol Chem 383:725-737.

Yanagiya T, Tanabe A, Hotta K (2007) Gap-junctional communication is required for mitotic clonal expansion during adipogenesis. Obesity (Silver Spring) 15:572582.

Zhu Y, Gao Y, Tao C, Shao M, Zhao S, Huang W, Yao T, Johnson JA, Liu T, Cypess AM, Gupta O, Holland WL, Gupta RK, Spray DC, Tanowitz HB, Cao L, Lynes MD, Tseng YH, Elmquist JK, Williams KW, Lin HV, Scherer PE (2016) Connexin 43 mediates white adipose tissue beiging by facilitating the propagation of sympathetic neuronal signals. Cell Metab 24:420-433. 